\title{
Article
}

\section{An Evaluation of the Contemporary Uses and Cultural Significance of Mammals in Mexico}

Ávila-Nájera, Dulce María, Naranjo, Eduardo J, Tigar, Barbara, Villarreal, Oscar and Mendoza, Germán David Mendoza

Available at http://clok.uclan.ac.uk/23593/

Ávila-Nájera, Dulce María, Naranjo, Eduardo J, Tigar, Barbara ORCID: 00000001-6037-3544, Villarreal, Oscar and Mendoza, Germán David Mendoza (2018) An Evaluation of the Contemporary Uses and Cultural Significance of Mammals in Mexico. Ethnobiology Letters, 9 (2). ISSN 2159-8126

It is advisable to refer to the publisher's version if you intend to cite from the work. 10.14237/ebl.9.2.2018.1106

For more information about UCLan's research in this area go to http://www.uclan.ac.uk/researchgroups/ and search for < name of research Group>.

For information about Research generally at UCLan please go to http://www.uclan.ac.uk/research/

All outputs in CLoK are protected by Intellectual Property Rights law, including Copyright law. Copyright, IPR and Moral Rights for the works on this site are retained by the individual authors and/or other copyright owners. Terms and conditions for use of this material are defined in the policies page.

\section{CLoK}

Central Lancashire online Knowledge www.clok.uclan.ac.uk

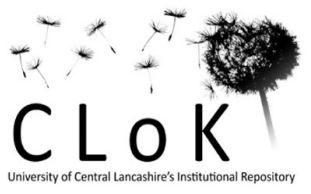


Research Communications

OPEN ə ACCESS

\title{
An Evaluation of the Contemporary Uses and Cultural Significance of Mammals in Mexico
}

\author{
Dulce María Ávila-Nájera1,5, Eduardo J. Naranjo², Barbara Tigar ${ }^{3 *}$, Oscar Villarreal ${ }^{4}$, and \\ Germán David Mendoza ${ }^{5}$
}

\begin{abstract}
1Unidad Académica de Biotecnología y Agroindustrial, Universidad Politécnica de Huatusco, Huatusco, Veracruz, México. ${ }^{2}$ Departamento de Conservación de la Biodiversidad, El Colegio de la Frontera Sur, San Cristóbal de las Casas, Chiapas, México. ${ }^{3 *}$ School of Forensic and Applied Sciences, University of Central Lancashire, Preston, UK. ${ }^{4}$ Facultad de Medicina Veterinaria y Zootecnia, Benemérita Universidad Autónoma de Puebla, Tecamachalco, Puebla, México. 5epartamento de Producción Agrícola y Animal, Universidad Autónoma Metropolitana, Unidad Xochimilco, Mexico City, México.

*btigar@uclan.ac.uk
\end{abstract}

Received September 18, 2017 | Accepted March 26, 2018

Ethnobiology Letters 2018 9(2):XX-XX | DOI 10.14237/ebl.9.2.2018.1106

\begin{abstract}
We evaluated current uses of wild mammals by indigenous and mestizo communities in Mexico by extracting data from 59 sources published or produced between 1987-2017, covering data from 240 localities and 3,905 questionnaires. We then calculated a Cultural Value Index (CVI) previously applied to plants to quantify resource use and assess the cultural significance of each mammal. A total of 82 species were reported, and the animals with the highest cultural importance according to their CVI (in brackets) were two species of deer (Odocoileus virginianus [18.32] and Mazama temama [10.04]), as well as the nine-banded armadillo (Dasypus novemcinctus [14.18]), white-nosed coati (Nasua narica [14.75]), collared peccary (Pecari tajaccu [11.90]), northern raccoon (Procyon lotor [11.28]) and spotted paca (Cuniculus paca [9.84]). The most common uses were for food, to reduce the damage or harm they cause, and for medicinal purposes, with $O$. virginianus, $P$. lotor, $N$. narica, and $D$. novemcinctus frequently hunted for all these reasons. Our analysis also highlighted the hunting of rarer species of national conservation concern, including commercial trading of body parts of the felids Panthera onca, Leopardus pardalis, and Leopardus wiedii. By quantifying the ethnozoological significance of wildlife to indigenous communities, indices such as CVI provide a robust measure of the extent of use and preference for particular species or taxa. This adds to the body of evidence used to develop effective regulations and laws related to harvesting and hunting, and helps promote a more sustainable and long-term approach to the use of natural resources.
\end{abstract}

Keywords: Cultural value index, Ethnozoology, Wildlife conservation, Conservation management

\section{Introduction}

Close human interactions with animals have occurred in all societies throughout our history (Alves 2012). These ethnozoological relationships go beyond simple utilitarian needs, such as for food, to complex superstitions and magic-religious associations (Alves et al. 2009; Alves et al. 2010; Prins et al. 2000). In some cultures, the continued use of a particular animal stems from a strong supernatural relationship established 
over thousands of years (Allaby 2010; Alves 2012). There is an increasing interest in the wider applications of such ethnozoological knowledge, including its value in informing conservation strategies and wildlife management decisions, particularly where cultural usage of a species is high (Alves and Souto 2015).

Wild mammals remain an important and widely used natural resource by indigenous and rural communities (Happold 1995; Alves et al. 2016). They provide a major source of protein, and have many other uses including ornamental, handicraft, medicinal, magical-religious symbolism, pets, trophy hunting, and commercial trading (Alves 2012). The benefits associated with each animal and the methods used to capture it are usually highly valued aspects of traditional cultures and vary with locality and ethnic group (Alves et. al. 2016; Robinson and Bennett 2000). In addition to being associated with benefits, some wild animals have a negative cultural significance because they are harmful to humans, livestock, goods, or property, and as a result they are controlled to mitigate the damage they cause. Therefore, cultural attitudes towards wildlife can be both positive and negative (Alves et al. 2012; Alves et al. 2016; Treves et al. 2006).

Mexico is highly biodiverse and culturally diverse (Sarukhán et al. 2009), and is ranked third globally for its species richness of mammals with 535 species (CONABIO 2008). Some mammals are preferred or more highly valued for particular uses, including ungulates, large rodents, armadillos, and felines, which are subject to high hunting pressures (Naranjo 2013).

Cunningham (2001) proposed allocating a numerical value to indicate the utility or benefit of each species based upon human perceptions of it and the extent of scientific or traditional knowledge about it (Purdy and Decker 1989). The advantage of using a quantitative index is that the results can be ordered by rank, which is useful when prioritizing species for decision-making purposes, as well as for spatial and temporal comparisons. Here we evaluate current ethnozoological knowledge on the extent of usage, types of uses, and cultural significance of mammals by rural communities in Mexico in a novel way by applying a Cultural Value Index (CVI) (Turner 1988) originally developed to quantify the ethnobotanical value of plant species-to another taxonomic group: mammals. Our aim was to generate a quantitative approach to help evaluate and develop effective strategies for the long-term conservation and sustainable use of mammals as well as other natural resources at local or regional levels in Mexico, which could be useful in other locations and cultures. Numerical measures of the ethnozoological significance, such as CVI, can provide evidence to inform and develop hunting regulations that more closely reflect the interests of the indigenous and mestizo communities who currently utilize wild mammals.

\section{Materials and Methods}

We systematically searched for research articles, books, theses, reports, and online material published or produced between 1987-2017, and extracted data on cultural values of, attitudes towards, and specific uses of mammals on a state by state basis in Mexico. We used the National Consortium of Scientific and Technological Information Resources (CONRICyT) database to access online ethnobiology journals, which are the main publishing option for many Mexican researchers. Where there were multiple articles by the same author(s), we avoided double counting by checking for unique place names or localities. We excluded records of domestic animals and corrected synonyms using Ceballos and Arroyo-Cabrales (2012). Records of resource-use by 
species were grouped into 11 categories for analysis: food, pets, trade, ornamental, artisanal, magic-religious, medicinal, sports hunting, recreational (species persecuted for amusement), harmful, and other benefits. The last of these categories includes a few animals used to control harmful species or those with secondary benefits, such as guano production by bats (Cossio 2007).

Turner's (1988) Cultural Value Index (CVI) was applied to the published data for each mammal species using the following equation:

$\mathrm{CVI}=\Sigma(\mathrm{Iu}+\mathrm{Fm}+\mathrm{Vut})$

Where:

Iu (Intensity of use) $=$ (Number of uses for each species from all sources / Total number of uses for all species from all sources) $\mathrm{x} 100$

Fm (Frequency of use $)=$ (Number of records [times a species is mentioned] of all uses for each species from all sources / Total number of records of all uses for all species from all sources) $\times 100$

$\mathrm{Vu}$ (Use value) $=$ (Number of records for each species of a single use from all sources / Total number of records of a single use for all species from all sources) $\mathrm{x} 100$

Vut (Total use value for each species) $=$ sum of $\mathrm{Vu}$ for all uses / total uses.

\section{Results}

We found 59 sources documenting indigenous and mestizo cultural use of mammals (Supplementary Table 1). These consisted of information described in interviews with 3,905 individuals at 240 localities, with records for 17 Mexican federal states, particularly the southern states of Campeche, Oaxaca, and Chiapas (Figure 1). There were a total of 1,727 recorded uses for 82 mammal species in Mexico, representing 54 genera, 21 families, and 11 orders (Table 1), particularly the orders Carnivora and Rodentia (24 and 28 species, respectively). About a third of these mammals were considered endangered $(n=6)$, at risk of extinction $(n=15)$, or subject to special protection $(n=6)$ in Mexico (Table 1). Mammals were mainly taken for food $(36.5 \%)$ or killed to prevent damage or harm (14\%), as well as for ornamentation (10\%), trade (8\%), and artisanal use (6.5\%), with $<2 \%$ having other uses (Figure 2 ). 


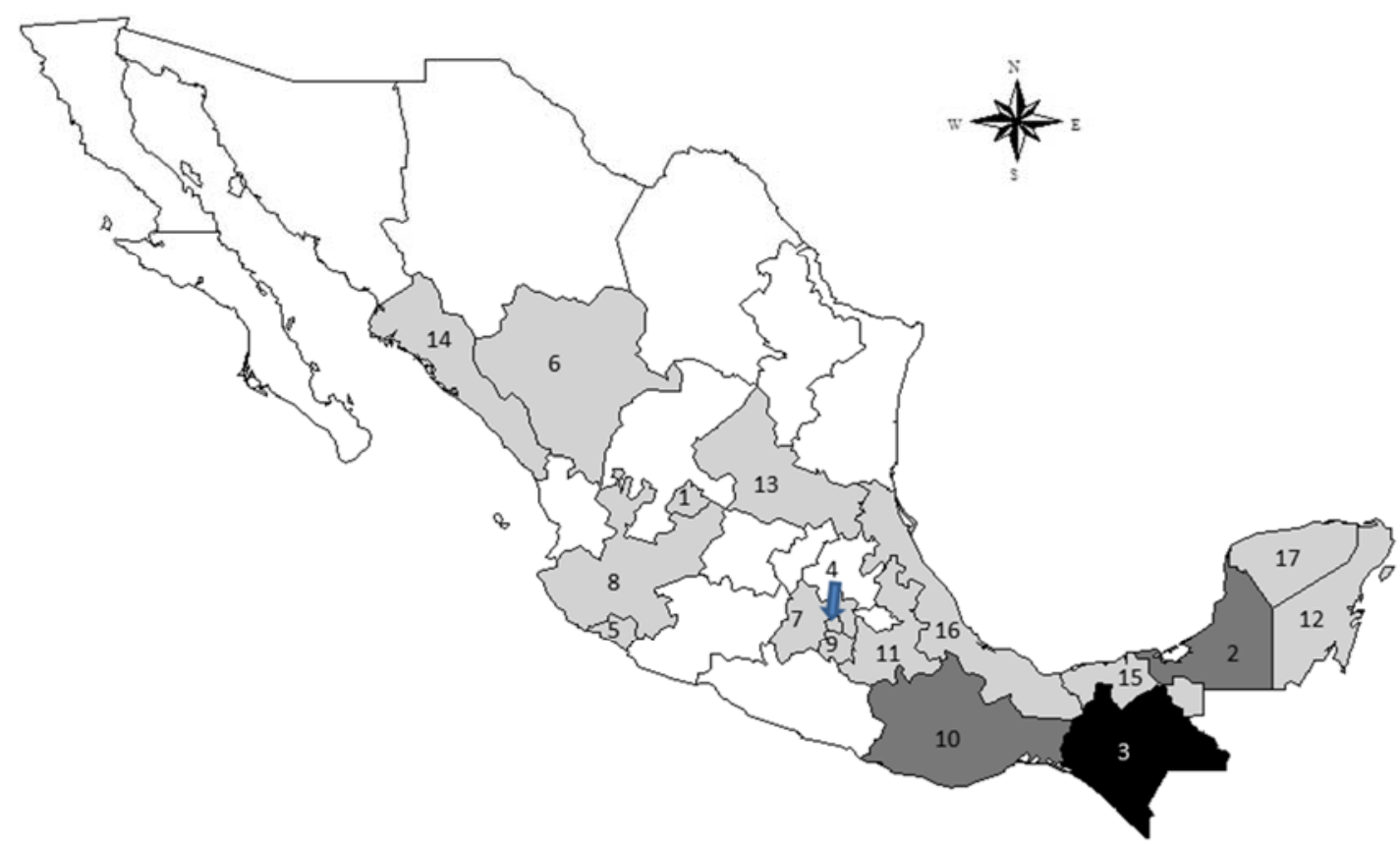

Figure 1 The location of the 17 Mexican federal states (labels 1-17) that had records for cultural uses of mammals used to calculate Cultural Value Indices (CVIs) for the 82 species. The shading indicates the number of independent sources used to calculate the CVIs, where light gray is $<5$ (1, Aguascalientes; 4 , México City; 5, Colima; 6, Durango; 7, Estado de México; 8, Jalisco; 9, Morelos; 11, Puebla; 12, Quintana Roo; 13, San Luis Potosí; 14, Sinaloa; 15, Tabasco; 16, Veracruz; 17, Yucatán); dark gray is between 5 and 10 (2, Campeche and 10, Oaxaca); and black indicates 16 sources (3, Chiapas).

Table 1 Taxonomic classification of wild mammal species with their national conservation status according to the NOM-059-SEMARNAT-2010 (SEMARNAT 2010) where E=Endangered or threatened, $\mathrm{R}=\mathrm{At}$ risk of extinction, and $\mathrm{P}=$ Subject to special protection measures; Total number of uses reported in Mexico (from a total of 11 types of use) and Cultural Value Index (CVI) are also reported. Species with high CVIs (CVI>10) are shown in bold.

\begin{tabular}{llll} 
Taxonomic Classification & $\begin{array}{l}\text { Conservation } \\
\text { Status }\end{array}$ & $\begin{array}{l}\text { Number of } \\
\text { Uses Reported }\end{array}$ & CVI \\
\hline ORDER ARTIODACTYLA & & & \\
FAMILY CERVIDAE & & 10.04 \\
Mazama temama & 9 & 1.75 \\
Odocoileus hemionus & 43 & 18.32 \\
Odocoileus virginianus & 11 & \\
FAMILY TAYASSUIDAE & & 11.90 \\
Pecari tajacu & & 5.75 \\
Tayassu pecari & 9 &
\end{tabular}

ORDER CARNIVORA

FAMILY CANIDAE 
FAMILY FELIDAE

Leopardus pardalis

Leopardus wiedii

Lynx rufus

Puma concolor

Panthera onca

R

Puma yagouaroundi

E

FAMILY MEPHITIDAE

Conepatus leuconotus

Conepatus semistriatus

$\mathrm{P}$

1.64

Conetaptus spp

1.50

Mephitis spp

Mephitis macroura

Spilogale gracilis

Spilogale putorius

Spilogale pygmaea

$\mathrm{R}$

1.08

1.09

5.02

0.66

1.50

FAMILY MUSTELIDAE

Eira barbara

$\mathrm{R}$

Galictis vittata

Lontra longicaudis

E

Mustela frenata

Taxidea taxus

E

FAMILY PROCYONIDAE

Bassariscus astutus

E

0.46

Bassariscus sumichrasti

P

Nasua narica

14.75

Potos flavus

P

Procyon lotor

10

ORDER CHIROPTERA

FAMILY MOLOSSIDAE

Tadarida brasiliensis

1

FAMILY PHYLLOSTOMIDAE

Artibeus jamaicensis

ORDER CINGULATA

FAMILY DASYPODIDAE

Cabassous centralis

$\mathrm{R}$

Dasypus novemcinctus 
FAMILY DIDELPHIDAE

Caluromys derbianus

E

0.37

Chironectes minimus

$\mathrm{R}$

0.34

Didelphis

1.77

Didelphis marsupialis

3.18

Didelphis virginiana

4.35

Marmosa mexicana

0.43

Philander opossum

1.75

ORDER LAGOMORPHA

FAMILY LEPORIDAE

Lepus

10

2.57

Lepus alleni

$\mathrm{P}$

1.05

Lepus flavigularis

Romerolagus diazi

$\mathrm{R}$

0.67

$\mathrm{R}$

0.32

Sylvilagus audubonii

1.24

Sylvilagus brasiliensis

1.74

Sylvilagus cunicularius

2.60

Sylvilagus floridanus

7.48

Sylvilagus spp

2.27

ORDER PERISSODACTYLA

FAMILY TAPIRIDAE

Tapirus bairdii

$\mathrm{R}$

ORDER PILOSA

FAMILY CYCLOPEDIDAE

Cyclopes didactylus

$\mathrm{R}$

0.58

FAMILY MYRMECOPHAGIDAE

Tamandua mexicana

$\mathrm{R}$

ORDER PRIMATES

FAMILY ATELIDAE

Alouatta palliata

$\mathrm{R}$

3.20

Ateles geoffroyi

$\mathrm{R}$

6.06

ORDER RODENTIA

FAMILY AGOUTIDAE

Dasyprocta

0.32

Dasyprocta mexicana

1.08

Dasyprocta punctata

2

5.31

FAMILY CUNICULIDAE

Cuniculus paca

8

9.84

FAMILY ERETHIZONTIDAE 
FAMILY GEOMYIDAE

Heteromys desmarestianus

Heteromys gaumeri

Heteromys spp

0.34

Orthogeomys grandis

Orthogeomys hispidus

Orthogeomys sp

Pappogeomys bulleri

FAMILY MURIDAE

Microtus mexicanus

Neotoma mexicana

Neotoma phenax

$\mathrm{P}$

Neotoma spp

Ototylomys phyllotys

Peromyscus aztecus

Peromyscus levipes

Peromyscus mexicanus

Peromyscus spp

Peromyscus yucatanicus

Peromyscus zarhynchus

Reithrodontomys spp

0.32

0.69

Sigmodon hispidus

0.34

Tylomys nudicaudus

FAMILY SCIURIDAE

Ammospermophilus interpres

Otospermophilus variegatus

Sciurus aureogaster

Sciurus colliaei

Sciurus deppei deppei

Sciurus nayaritensis

0.32

Sciurus spp

5.01

Sciurus yucatanensis

2.58

ORDEN SIRENIA

FAMILY TRICHECHIDAE

Trichechus manatus 


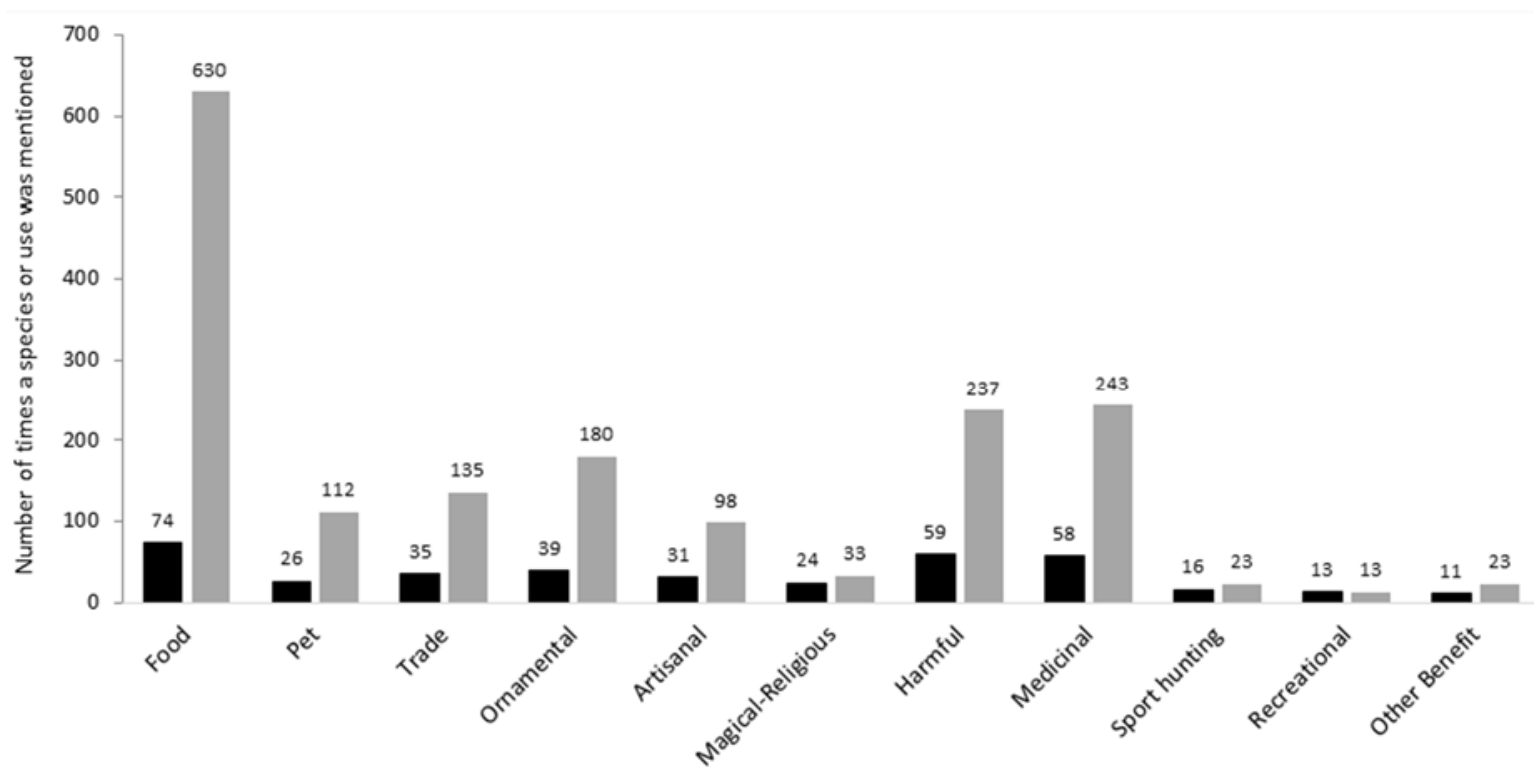

Figure 2 Total number of mammal species reported to have a particular use or benefit (black bars) and the total number of times a specific cultural use of a mammal was mentioned (gray bars) in all literature sources for Mexico published between 1987-2017.

The CVI scores varied from 0.03 for species with a single record of use, to 15 for frequently mentioned species with multiple uses (Table 1). The CVIs suggest that the most frequently used species were white-tailed deer (Odocoileus virginianus, 18.32), white-nosed coatis (Nasua narica, 14.75), nine-banded armadillos (Dasypus novemcinctus, 14.18), collared peccaries (Pecari tajacu, 11.90), northern raccoons (Procyon lotor, 11.28), Central American red brocket deer (Mazamma temama, 10.04), spotted pacas (Cuniculus paca, 9.84), jaguars (Panthera onca, 9.02), tigrillos (Leopardus wiedii, 7.87), and pumas (Puma concolor, 7.48).

The most frequent reason for using mammals was for food, and the most commonly consumed species were D. novemcinctus (6.82), $N$. narica (6.66), O. virginianus (6.34), $P$. tajacu (6.03), and P. lotor (5.07); numbers in parenthesis are the frequency with which a species was mentioned for that use. Another common reason for hunting was to reduce the damage or harm associated with a species, particularly for $N$. narica (6.75), $P$. lotor (5.48), and P. concolor (4.21). Medicinal use was also common, and included $D$. novemcinctus (7.81), O. virginianus (6.17), Mephitis macroura (hooded skunks) (6.17), and $N$. narica (5.34). The most frequently commercially traded mammals were $O$. virginianus (9.62), P. onca (8.88), C. paca (6.66), P. concolor (5.18), Leopardus pardalis (ocelots) (5.18), and L. wiedii (5.18).

\section{Discussion}

Recent ethnozoological studies have shown that native and rural populations have a deep-rooted knowledge of wildlife and nature, which they apply when interacting with or exploiting natural resources (Mourão et al. 2006; Mourão and Nordi 2002; Souto et al. 2011). This traditional knowledge has been passed down through many generations and is finding new applications as a tool to inform faunal inventories, as well as zoological and ecological research (Alves and Souto 2015; Alves et al. 2016). While ethnobotany is well-established, the emergence of ethnozoology helps to emphasize the social and economic value of regional fauna (Cullen et al. 2000; Léopold et al. 2009) and 
provides evidence to inform environmental impact assessments, resource management, and sustainable development (Alves and Souto, 2015; Johannes 1993; Sillitoe 1998).

Our CVI results for Mexico show widespread levels of hunting and diverse uses of wild mammals, particularly large and medium-sized species like deer and peccaries, which are a major source of meat in many rural areas. However, 27 (33\%) of the mammals currently used are considered to be at risk of extinction in Mexico (SEMARNAT 2010), including the jaguar, tigrillo, ocelot, jaguarundi (Puma yagouaroundi), hare of the Isthmus of Tehuantepec (Lepus flavigularis), howler monkey (Alouatta palliata), spider monkey (Ateles geoffroyi), and tapir (Tapirus bairdii). In addition, many carnivores of national and global conservation concern have high CVI scores, suggesting they are particularly vulnerable to overuse.

Although subsistence hunting generally poses lower risks to wildlife than commercial hunting (Fa and Peres 2001), this depends on the level of hunting pressure and is often exacerbated by habitat degradation (Alves et al. 2016). The impact of hunting is generally highest on large and medium vertebrates, particularly species taken for human consumption (Alves et. al. 2016) or causing some form of damage or harm (Peres 2000; Redford 1992). Species with a relatively high CVI score require management that encourages sustainable harvesting. However, as CVIs reflect the values of a specific cultural group or locality, they can both help inform effective hunting laws or regulations that minimize the risk to wild populations, and bring long-term benefits to both wildlife and the people using them (Naranjo 2013; Robinson and Bennett 2000).

An example of good practice for frequently hunted species in Mexico is the establishment of special units for conservation management and the sustainable use of wildlife (Unidades para la conservacion, Manejo y Aprovechamiento de la vida silvestre [UMA]) (Gallina-Tessaro et al. 2009), where the economic harvesting of natural resources is controlled by the local communities that rely on them. Therefore, UMAs would benefit from considering CVIs when calculating harvesting rates, and when evaluating their long-term effectiveness and sustainability. Such an approach can be strengthened by other activities that reduce the overuse of wildlife, such as improving the levels of environmental education, wildlife surveillance, and opportunities for better-paid local employment (Naranjo 2008). In addition, promoting the local knowledge and traditions of those species most at risk helps to reinforce and maintain their cultural importance in a community (Purdy and Decker 1989).

Therefore, indices such as CVI, which quantify the importance of a species to a community, can complement accurate information on catch rates and populations sizes, leading to management strategies that support the long-term persistence of wildlife. Where suitable ethnobiological and ethnozoological information are available, conservation managers and wildlife biologists can incorporate CVI into the decisionmaking processes for any natural resource or locality. In addition, CVI can highlight the animals most frequently utilized by human communities and at highest risk of over harvesting, which in this study included several taxonomic groups including ungulates, big cats, and large rodents, known to be important indicators of the overall health and structure of an ecosystem (Miller et al. 2001).

\section{Acknowledgements}

The authors thank their respective Heads of Department at the Universidad Politecnica de Huatusco, El Colegio de la Frontera Sur, the University of Central Lancashire, and the 
Universidad Autónoma Metropolitana (Unidad Xochimilco), for supporting their collaboration on this original research idea. This research was made possible by funding to Dulce Maria Avila Nájera from the Secretaria de Educación Pública, Mexico, PostDoctoral research scholarship, UAM-X-CA-24. We also thank the editor and two anonymous referees for their constructive comments, which helped us to improve our article.

\section{Declarations}

Permissions:

Sources of Funding.

Conflicts of Interest.

\section{References Cited}

Allaby, M. 2010. Animals: From Mythology to Zoology. Facts On File, Inc., New York, NY.

Alves, R.R.N. 2012. Relationships Between Fauna and People and the Role of Ethnozoology in Animal Conservation. Ethnobiology and Conservation 1:1-69. DOI:10.15451/ec2012-8-1.2-1-69.

Alves, R.R.N., A. Feijó, R.R.D. Barboza, W.M.S. Souto, H. Fernandes-Ferrerira, P. CordeiroEstrela, and A. Langguth. 2016. Game Mammals of the Caatinga Biome. Ethnobiology and Conservation 5:1-55. DOI:10.15451/ec2016-7-5.5-1-51.

Alves, R.R.N., L.E.T. Mendonça, M.V.A. Confessor, W.L.S. Vieira, and L.C.S. Lopez. 2009. Hunting Strategies Used in the Semi-Arid Region of Northeastern Brazil. Journal of Ethnobiology and Ethnomedicine 5:1-50. DOI:10.1007/s10668-016-9827-2.

Alves, R.R.N., E. Nogueira, H. Araujo, and S. Brooks. 2010. Bird-Keeping in the Caatinga, NE Brazil. Human Ecology38:147-156. DOI:10.1007/s10745-009-9295-5.

Alves, R.R.N., I.L. Rosa, N.A. Léo-Neto, and R. Voeks. 2012. Animals for the Gods: Magical and Religious Faunal Use and Trade in Brazil. Human Ecology 40:751-780. DOI:10.1186/1746-4269-9-3.

Alves, R.R.N. and W.M.S. Souto. 2015. Ethnozoology: A Brief Introduction. Ethnozoology and Conservation 4:1-13. DOI:10.15451/ec2015-1-4.1-1-1.

Ceballos, G. and J. Arroyo-Cabrales. 2012. Lista Actualizada de los Mamíferos de México. Revista Mexicana de Mastozoología Nueva Epoca 2(1). Available at: http://www.revmexmastozoologia.unam.mx/ojs/index.php/rmm/article/view/20. Accessed on August 22, 2017.

Comisión Nacional para el Conocimiento y Uso de la Biodiversidad (CONABIO). 2008. EI Capital Natural de México. Vol. I. Conocimiento Actual de la Biodiversidad. Comisión Nacional para el Conocimiento y Uso de la Biodiversidad, México. Available at: http://www.biodiversidad.gob.mx/pais/conocimientoActual.html. Accessed on August 22, 2017.

Cossio, B.A. 2007. Cocimiento y Comparación del Uso de la Fauna Silvestre en Dos Comunidades Ejidales del Municipio de Hueytamalco, Puebla, México. Unpublished Master's Thesis, Instituto de Ecología, Xalapa, Mexico. 
Cullen, L., R.E. Bodmer, and C. Padua. 2000. Effects of Hunting in Habitat Fragments of the Atlantic Forests, Brazil. Biological Conservation 95:49-56. DOI:10.1016/s00063207(00)00011-2.

Cunningham, A.B. 2001. Applied Ethnobotany: People, Wild Plant Use, and Conservation. Earthscan, London and Stirling, UK.

Fa, J.E. and C.A. Peres. 2001. Game Vertebrate Extraction in African and Neotropical Forests: An Intercontinental Comparison. In Conservation of Exploited Species. Conservation Biology. Number 6, edited by J.D. Reynolds, G.M. Mace, K.H. Redford, and J.G. Robinson, pp. 203-241. Cambridge University Press, Cambridge, UK.

Gallina-Tessaro, S.A., A. Hernández-Huerta, C. Delfín-Alfonso, and A. González-Gallina. 2009. Unidades Para la Conservación, Manejo, y Aprovechamiento Sustentable de la Vida Silvestre en México (UMA). Retos para su Correcto Funcionamiento. Investigación Ambiental 1:142-152.

Happold, D.C.D. 1995. The Interactions between Humans and Mammals in Africa in Relation to Conservation: A Review. Biodiversity and Conservation 4:395-414. DOI:10.1007/BF00058424.

Johannes, R.E. 1993. Integrating Traditional Ecological Knowledge and Management with Environmental Impact Assessment. In Traditional Ecological Knowledge: Concepts and Cases, edited by J.T. Inglis, pp. 33-39. International Program on Traditional Ecological Knowledge and International Development Research Centre, Ottawa, Canada.

Léopold, M., A. Cakacaka, S. Meo, J. Sikolia, and D. Lecchini. 2009. Evaluation of the Effectiveness of Three Underwater Reef Fish Monitoring Methods in Fiji. Biodiversity and Conservation 18:3367-3382. DOI:10.1007/s10531-009-9646-y.

Miller, B., B. Dugelby, D. Foreman, C. Martinez del Río, R. Noss, M. Philips, R. Reading, M.E. Soulé, J. Terborgh, and L. Willcox. 2001. The Importance of Large Carnivores to Healthy Ecosystems. Endangered Species UPDATE18:202-2010.

Mourão, J.S., H.F.P. Araujo, and F.S. Almeida. 2006. Ethnotaxonomy of Mastofauna as Practised by Hunters of the Municipality of Paulista, State of Paraíba-Brazil. Journal of Ethnobiology and Ethnomedicine 2:1-7. DOI:10.1186/1746-4269-2-19.

Mourão, J.S. and N. Nordi. 2002. Comparações Entre as Taxonomias Folk e Científica Para Peixes do Estuário do Rio Mamanguape, Paraíba-Brasil. Interciencia 27:664-668.

Naranjo, E.J. 2008. Uso y Conservación de Mamíferos en la Selva Lacandona, Chiapas, México. In Avances en el Estudio de los Mamíferos de México II edited by C. Lorenzo, E. Espinoza, and J. Ortega, pp. 675-691. Asociación Mexicana de Mastozoología, A.C. (AMMAC). San Cristóbal de Las Casas, México.

Naranjo, E.J. 2013. Uso de la Fauna Silvestre. In La Biodiversidad de Chiapas: Estudio de Estado, edited by A. Cruz-Angón, E.D. Melgarejo, F. Camacho-Rico, and K.C. NájeraConchero, pp. 271-280. Comisión Nacional Para el Conocimiento y Uso de la Biodiversidad (CONABIO) and Gobierno del Estado de Chiapas, Mexico City, México.

Peres, C.A. 2000. Evaluating the Impact and Sustainability of Subsistence Hunting at Multiple Amazonian Forest Sites. In Hunting for Sustainability in Tropical Forests, edited by J.G. Robinson and E. Bennett, pp. 31-56. Columbia University Press, New York, NY. 
Prins, H.H.T., J.G. Grootenhuis, and T.T. Dolan. 2000. Wildlife Conservation by Sustainable Use. Kluwer Academic Publisher, Boston, MA.

Purdy, K. and D. Decker. 1989. Applying Wildlife Values Information in Management: The Wildlife Attitudes and Values Scale. Wildlife Society Bulletin 17:494-500.

Redford, K.H. 1992. The Empty Forest. Bioscience 42:412-422. DOI:10.2307/1311860.

Robinson, J.G. and E.L. Bennett. 2000. Hunting for Sustainability in Tropical Forests. Columbia University Press, New York, NY.

Sarukhán, J., P. Koleff, J. Carabias, J. Soberón, R. Dirzo, J. Llorente-Bousquets, G. Halffter, R. González, I. March, A. Mohar, S. Anta, and J. De La Maza. 2009. Capital Natural de México: Conocimiento Actual, Evaluación y Perspectivas de Sustentabilidad. Síntesis. Report for Comisión Nacional Para el Conocimiento y Uso de la Biodiversidad (CONABIO), México. Available at:

http://www.biodiversidad.gob.mx/pais/pdf/CapNatMex/Capital\%20Natural\%20de\% 20Mexico_Sintesis.pdf. Accessed on August 22, 2017.

Secretaría de Medio Ambiente y Recursos Naturales (SEMARNAT). 2010. Norma Oficial Mexicana NOM-059-SEMARNAT-2010. Protección Ambiental, Especies Nativas de Flora y Fauna Silvestres de México, Categorías de Riesgo y Especificaciones Para su Inclusión, Exclusión o Cambio, y Lista de Especies en Riesgo. Diario Oficial de la Federación [web page]. URL: https://www.gob.mx/profepa/documentos/normaoficial-mexicana-nom-059-semarnat-2010. Accessed on August 22, 2017.

Sillitoe, P. 1998. The Development of Indigenous Knowledge. Current Anthropology 39:223-252. DOI:10.1086/204722.

Souto, W.M.S., J.S. Mourão, R.R.D. Barboza, and R.R.N. Alves. 2011. Parallels Between Zootherapeutic Practices in Ethnoveterinary and Human Complementary Medicine in NE Brazil. Journal of Ethnopharmacology 134:753-767. DOI:10.1016/j.jep.2011.01.041.

Treves, A., R.B. Wallace, L. Naughton-Treves, and A. Morales. 2006. Co-Managing Human-Wildlife Conflicts: A Review. Human Dimensions of Wildlife 11:383-396. DOI:10.1080/10871200600984265.

Turner, N. 1988. The Importance of a Rose, Evaluating the Cultural Significance of Plants in Thompson and Lilloet Interior Salish. American Anthropologist New Series 90:272290. 